\title{
Is the population of Crotalus durissus (Serpentes, Viperidae) expanding in Brazil?
}

\author{
Marcelo Ribeiro Duarte* and Frederico Alcântara Menezes
}

\begin{abstract}
Crotalus durissus are found from Mexico to northern Argentina in a highly disjunct distribution. According to some studies, this species is prone to occupy areas disturbed by human activities and floods comprise a plausible method of dispersal as inferred for some North American rattlesnakes. Based on the literature, it seems plausible that Crotalus durissus expanded their natural distribution in Brazil due to floods, but only in a few municipalities in Rio de Janeiro State. Data entries of Butantan Institute, in São Paulo, Brazil, from 1998 to 2012 show a declining tendency of snakes brought by donors. In addition, research shows no evidence of Crotalus durissus being an expanding species in the Brazilian territory.
\end{abstract}

Keywords: Rattlesnake, Habitat degradation, Species conservation, Animal distribution

\section{Findings}

It seems unquestionable that the wide-ranging Crotalus durissus complex is derived from a North American ancestor that spread towards South America [1]. These snakes are found in seasonally dry formations from Mexico to northern Argentina, but are absent from the Central American and Amazonian rainforests [1]. This highly discontinuous distribution includes open habitats both north and south of the Amazon rainforest as well as isolated open formations within it, avoiding the forest itself [2]. Crotalus durissus is likely to be found in areas disturbed by human activities and takes advantage of the effects of deforestation in Atlantic rainforest regions [3-5].

According to Klauber [6], although floods are an important method of dispersal of rattlesnakes, after severe ones, Sistrurus catenatus population tends to decrease due to reduced prey availability [7]. Indeed, this natural transport was considered the dispersal mode for Brazilian rattlesnakes in some localities of Rio de Janeiro State during the 1950s [8]. In addition, Atlantic forest fragmentation has been suggested as responsible for Crotalus durissus territorial expansion and supposed increased density [4]. Bastos et al. [8] proposed that this picture may represent the recent invasion of the species into disturbed areas of the Atlantic forest. In this brief correspondence, we examine

\footnotetext{
* Correspondence: marcelo.duarte@butantan.gov.br

Laboratory of Zoology Collection, Butantan Institute, Av. Vital Brazil, 1500 São Paulo, CEP: 05503-900, São Paulo State, Brazil
}

the growing reputation of Crotalus durissus as an expanding species in Brazil, highlighting the implications for land use, distribution, conservation, and epidemiology since this species is responsible for $7.7 \%$ of the 20.000 human snakebites that occur in Brazil annually [9]. Entry records of Crotalus durissus specimens from the whole Brazilian territory at Butantan Institute (IBSP), a traditional research center, between 1988 and 1990 were compared with those of 1991, 1997-2012 (data from 2003 missing), and statistically analyzed by Past ${ }^{\circ}$ software (Figure 1) [4].

The gap between 1992 and 1996 is a result of lack of data in the annual reports of Butantan Institute. Records of Crotalus durissus specimens found in the Rio de Janeiro State in the Museum of Zoology of the University of São Paulo - MZUSP (SP state), Vital Brazil Institute - IVB (RJ state), National Museum of Rio de Janeiro - MNRJ (RJ state), and IBSP are listed in Appendix.

Since the ratio of Crotalus durissus received by IBSP was considered greater than that of Bothrops jararaca by Sazima [4], and in order to compare and statistically confirm such tendency, we analyzed the entry of both species in the following periods: 1988-1990, 1991, and 1997-2012.

Regression analysis showed decreasing values for both species in the period $\left(R^{2}=0.89\right.$ and 0.70 respectively, and $p=0.0001$ ). Analysis of covariance showed no difference among species in number of entries, regardless of the year, as well as in the decreasing rate among species 


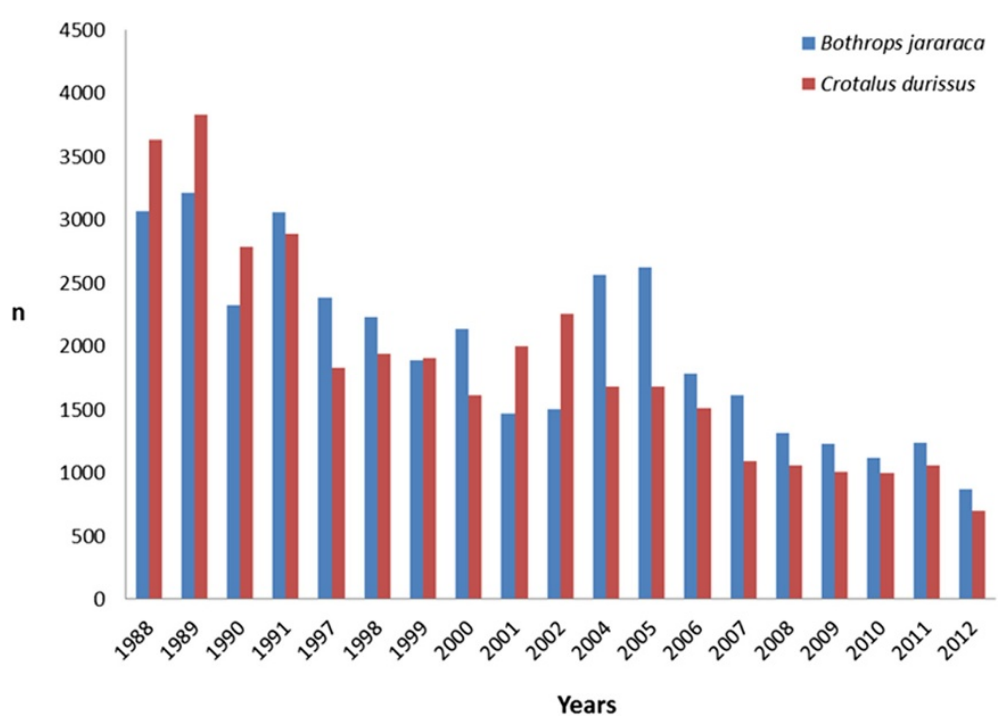

Figure 1 Entry of Bothrops jararaca and Crotalus durissus (Serpentes, Viperidae) per year at Butantan Institute, São Paulo, SP, Brazil.

during the period $(\mathrm{F}=3.87, \mathrm{p}=0.0573)$. Crotalus durissus has no voucher specimens from Rio de Janeiro State in MZUSP, and only one specimen is available outside Brazil at the American Museum of Natural History AMNH, New York, USA [10]. Although lacking some specimens to be added to their herpetological collections, IVB and MNRJ are together harboring sixty specimens of Crotalus durissus from Rio de Janeiro state. These records began in 1988 in IVB and in 2007 in MNRJ.

\section{Closing remarks}

Species face the challenge of living and coexist in complex landscape mosaics that include original habitats, new environments, and urban and agricultural zones $[11,12]$. Regardless of the motivation, the desire to conserve reptiles and to better understand their ecology requires knowledge of their status, distribution, and factors that contribute to the decline or increase of their population [13].

It appears to be consensual that Crotalus durissus is prone to occupy areas disturbed by human activities $[3,4,8,14,15]$. However, the suitability of Crotalus durissus for cleared areas and the edge effects on performance and population dynamics is based only on the authors' personal experience. In fact, there is substantial discrepancy among recent studies about the existence and intensity of edge effects [16].

According to Tozetti and Martins [15], the combination of shaded and exposed substrate could increase the thermoregulatory possibilities for rattlesnakes in Atlantic forest areas transformed by human activity due to the species low thermal selectivity. However, supposed expansive propensities are counterbalanced by several underrated limiting processes (e.g. inadequate shelter and microclimate, competition, prey availability, ants; predators, parasites, and diseases) in a mosaic landscape $[4,14]$.

If intensive agricultural practices are considered, a fair analysis would have to consider other aspects in the equation, since important levels of disturbance factors like machinery displacement, fire, exposition to soil corrective and supplementary nutrients as well as pesticides must be accounted. In fact, stressor factors such as habitat degradation and human predation affect snake population as well as unrestrained development, pollution, unwise land use practices and contaminants $[13,17,18]$.

Conversion of natural fragments into agricultural fields versus snake survival is a doubtful matter [19]. Landscapescale disturbances, such as grazing, fire, residential development, agriculture, and forestry, occur throughout the habitat of Crotalus from North America to Uruguay and Brazil $[20,21]$. Only a few crotalines receive special protection and even fewer have been subjected to detailed assessment of their conservation status [22].

From the epidemiological viewpoint, the statement that the historic distribution of Crotalus durissus does not include Rio de Janeiro state until the 1990s is not true [23]. In fact, there are voucher specimens from this state (see Appendix) from the municipalities of Niterói (AMNH 27731: 1940) and Miracema (IBSP 11265, 11266: 1947) [10]. Some evidence of this involuntary colonist in Rio de Janeiro state could be based on the lack of epidemiological records [24-26]. Additionally, it is reasonable to believe in the hypothesis of natural transport by floods; since it is highly unlikely that such a large snake would have gone unnoticed [8,27].

Typical limitations of studies related to the effects of habitat change on tropical herpetofauna include the lack 
of reliable baseline [28]. Moreover, we suggested caution against the claim that cleared areas per se will provide Crotalus durissus adaptation improvement. To conserve herpetofauna in urban areas (or in degraded landscape) structural complexity in remnant habitat patches must be maintained [29].

At least for rattlesnake species from North America, Uruguay, Amazonian savanna enclaves, and Aruba Island the scenario is not promising [17,20,21,30-35]. The perspective that rattlesnakes are expanding their territory in Brazil creates a false perception that this animal does not deserve concern or even protection. Clearly, careful studies taking into account the above-mentioned variables are essential to document temporal changes in rattlesnake populations in Brazil. To the best of our knowledge, such research has not been carried out yet.

\section{Appendix}

\section{Vouchers of Crotalus durissus from Rio de Janeiro state, Brazil}

AMNH Niterói: 27731.

IBSP Barra Mansa: 17144, 54911, 55712; Barra do Piraí: 40055, 48087; Miracema: 11265, 11266, 29290; Paraíba do Sul: 54665, 54731; Paraty: 31818; Resende: 67981; Rio das Flores: 60650; Três Rios: one record without voucher (February, 5, 1998); Valença: 26718, 51418, 51426, 51797, 52877, 52878, 52879, 55531, 55532, 55533, 55534.

IVB Areal: 2772; Itatiaia: 645; Paraíba do Sul: 1390, 1409, 1577, 2207; Três Rios: 2763, Valença (1990-1996): $1658,1665,1698,1869,1954,1955,1986,2070,2090$, 2102, 2103, 2107, 2108, 2157, 2175, 2201, 2249, 2412, 2419, 2420, 2428, 2429, 2430, 2431, 2433, 2450, 2459, 2462, 2501, 2509, 2691, 2713, 2778, 2877, 2920*; Volta Redonda: 1502.

MNRJ: BR 040 km 797: 20792; Rio das Flores: 16976-79, 16974-75, 18173; Valença: 19495-97.

MZUSP: No records.

*According to Bastos [8], IVB received 82 specimens from this locality between 1999-2003.

\section{Abbreviations}

AMNH: American museum of natural history, New York, USA; IBSP: Herpetological collection "Alphonse Richard Hoge", Butantan Institute, São Paulo, SP, Brazil; IVB: Vital Brazil Institute, Niterói, RJ, Brazil; MNRJ: National Museum, Rio de Janeiro, RJ, Brazil; MZUSP: Museum of Zoology of the University of São Paulo, São Paulo, SP, Brazil.

\section{Authors' contributions}

MRD participate in the design of the study and drafted the manuscript. FAM carried out the data acquisition and statistical analysis. Both authors read and approved the final manuscript.

\section{Acknowledgements}

We are grateful to Rodrigo Castellari (MNRJ) for his help regarding the snake collection; to Paulo Passos (MNRJ), Aníbal Melgarejo (IVB), Carolina Castro-Mello, and Hussam El-Dine Zaher (MZUSP) for collection data records; and to André Eterovic (UFABC) for statistical approach.
Received: 14 November 2013 Accepted: 2 December 2013

Published: 5 December 2013

\section{References}

1. Campbell JA, Lamar WW: The venomous reptiles of the Western Hemisphere. Ithaca: Cornell University Press; 2004.

2. Wüster W, Ferguson JE, Quijada-Mascareñas JA, Pook CE, Salomão Mda G, Thorpe RS: Tracing an invasion: landbridges, refugia, and the phylogeography of the Neotropical rattlesnake (Serpentes: Viperidae: Crotalus durissus). Mol Ecol 2005, 14(4):1095-1108.

3. Sant'Anna SS, Abe AS: Diet of the rattlesnake Crotalus durissus in southeastern Brazil (Serpentes, Viperidae). Stud Neotrop Fauna E 2007, 42(3):169-174.

4. Sazima I: Natural history of the jararaca pitviper, Bothrops jararaca, in southeastern Brazil. In Biology of the Pitvipers. Edited by Campbell JA, Brodie ED. Texas: Selva; 1992:199-216.

5. Sazima I, Haddad CFB: Répteis da Serra do Japi: notas sobre história natural. In História natural da Serra do Japi: Ecologia e preservação de uma área florestal no Sudeste do Brasil. Edited by Morellato LPC. Campinas: Unicamp e Fapesp; 1992:212-326.

6. Klauber LM: Rattlesnakes: their habits, life histories, and influence on mankind. Berkeley: University of California Press; 1984.

7. Seigel RA, Sheil CA, Doody JS: Changes in a population of an endangered rattlesnake Sistrurus catenatus following a severe flood. Biol Conserv 1998, 83(2):127-131.

8. Bastos EGM, Araújo AFB, Silva HR: Records of the rattlesnakes Crotalus durissus terrificus Laurenti (Serpentes, Viperidae) in the State of Rio de Janeiro, Brazil: a possible case of invasion facilitated by deforestation. Rev Bras Zool 2005, 22(3):812-815

9. Araújo FAA, Santalucia M, Cabral RF: Epidemiologia dos Acidentes por Animais Peçonhentos. In Animais peçonhentos no Brasil: biologia, clínica e terapêutica dos acidentes. Edited by Cardoso $\mathrm{L}$, Franca FO, Wen FH, Málaque CM, Haddad V Jr. São Paulo: Sarvier; 2003:6-12.

10. Gloyd HK: The rattlesnakes, genera Sistrurus and Crotalus. A study in zoogeography and evolution. Special Publications of the Chicago Academy of Sciences 1940, 4:1-27.

11. Sazima I, Manzani PR: As cobras que vivem numa reserva florestal urbana. In Ecologia e preservação de uma floresta tropical urbana: Reserva de Santa Genebra. Edited by Morellato PC, Leitão-Filho HF. São Paulo: Unicamp; 1995:78-82.

12. Rojas-Morales JA: Snakes of an urban-rural landscape in the central Andes of Colombia: species composition, distribution, and natural history. Phyllomedusa 2012, 11(2):135-154.

13. Todd BD, Willson JD, Gibbons JW: The global status of reptiles and causes of their decline. In Ecotoxicology of Amphibians and Reptiles. 2nd edition. Edited by Sparling DW, Linder G, Bishop CA, Krest SK. Boca Raton: CRC Press; 2010:47-67.

14. Melgarejo AR: Serpentes peçonhentas do Brasil. In Animais peçonhentos no Brasil: biologia, clínica e terapêutica dos acidentes. Edited by Cardoso JL, Franca FO, Wen FH, Málaque CM, Haddad V Jr. São Paulo: Sarvier; 2003:33-61.

15. Tozetti AM, Martins M: Habitat use by the South-American rattlesnake (Crotalus durissus) in south-eastern Brazil. J Nat Hist 2008, 42(19-20):1435-1444.

16. Murcia C: Edge effects in fragmented forest: implications for conservation. Trends Ecol Evol 1995, 10(2):58-62.

17. Dodd CK Jr: Status, conservation, and management. In Snakes: ecology and evolutionary biology. Edited by Seigel RA, Novak SS, Collins JT. New York: MacGraw-Hill; 1987:478-513.

18. Reinert HK, Rupert RR Jr: Impacts of translocation on behavior and survival of timber rattlesnakes, Crotalus horridus. J Herpet 1999, 33(1):45-61

19. Weatherhead PJ, Madsen T: Linking behavioral ecology to conservation objectives. In Snakes: ecology and conservation. Edited by Mullin SJ, Seigel RA. Ithaca: Cornell University press; 2009:149-171.

20. Jenkins $C L$, Peterson $C R$ : A trophic-based approach to the conservation biology of rattlesnakes: linking landscape disturbance to rattlesnake population. In The Biology of Rattlesnakes. Edited by Hayes WK, Beaman KR, Cardwell MD, Bush SP. California: Loma Linda University Press; 2008:265-274.

21. Bèrnils RS, Giraudo AR, Carreira S, Cechin SZ: Répteis das porções subtropical e temperada da região neotropical. Ciênc Ambient 2007, 35:101-136 
22. Greene HW, Campbell JA: The future of pitvipers. In Biology of the pitvipers. Edited by Campbell JA, Brodie ED. Texas: Selva; 1992:216-421.

23. Machado C, Bochner R: Information of crotalic envenomation in State of Rio de Janeiro, 2001 to 2010. Gaz Méd Bahia 2012, 82(Suppl. 1):78-84.

24. Barroso RD: Ofidismo no Brasil: considerações em torno de 2238 acidentes ofídicos tratados com soro. Bol Inst Vital Brazil 1944, 26:35-47.

25. Machado O: Nota sobre as serpentes venenosas do Estado do Rio. Bol Inst Vital Brazil 1944, 26:58-60.

26. Silva M Jr: O Ofidismo no Brasil. Rio de Janeiro: Ministério da Saúde: Serviço Nacional de Educação Sanitária; 1956.

27. von Ihering R: Cobras e amphibios das ilhotas de "Aguapé". Rev Mus Paulista 1911, 8:454-461.

28. Gardner TA, Ribeiro-Junior MA, Barlow J, Avila-Pires TC, Hoogmoed MS, Peres CA: The value of primary, secondary, and plantation forests for a neotropical herpetofauna. Conserv Biol 2007, 21(3):775-787.

29. Hamer AJ, McDonnell MJ: The response of herpetofauna to urbanization: inferring patterns of persistence from wildlife databases. Austral Ecol 2010, 35(5):568-580.

30. Meik JM, Deloya EM, Setser K: New distribution records from the Querétero dusky rattlesnake Crotalus aquilus (Viperidae), with comments on morphology and habitat use. West N Am Naturalist 2007. 67(4):601-604.

31. Andrews KM, Gibbons JW: Roads as catalysts of urbanization: snakes on roads face differential impacts due to inter- and intraspecific ecological attributes. In Urban Herpetology. Edited by Mitchell JC, Jung Brown RE, Bartholomew B. Salt Lake City: Society for the Study of Amphibians and Reptiles; 2008:145-153. Herpetological Conservation no. 3.

32. Carreira S, Meneghel M, Achaval F: Reptiles de Uruquay. Montevideo, Di. R. A. C: Faculdad de Ciencias, Universidad de la República; 2005.

33. França FGR, Mesquita DO, Colli GR: A checklist of snakes from Amazonian savannas in Brazil, housed in the Coleção herpetológica of Universidade de Brasilia with new distribution records, Edição 17 de Occasional papers. Oklahoma: Sam Noble Okhlahoma Museum of Natural History; 2006:1-13.

34. De Boer BA: Nos bestianan, onze dieren, our animals, Curaçao, Bonaire, Aruba. Curaçao: Stichting Dierenbescherming; 2001.

35. King RB: Population and conservation genetics. In Snakes: Ecology and Conservation. Edited by Mullin SJ, Seigel RA. Ithaca: Cornell University press: 2009:78-122.

doi:10.1186/1678-9199-19-30

Cite this article as: Duarte and Menezes: Is the population of Crotalus durissus (Serpentes, Viperidae) expanding in Brazil? Journal of Venomous Animals and Toxins including Tropical Diseases 2013 19:30.

\section{Submit your next manuscript to BioMed Central and take full advantage of:}

- Convenient online submission

- Thorough peer review

- No space constraints or color figure charges

- Immediate publication on acceptance

- Inclusion in PubMed, CAS, Scopus and Google Scholar

- Research which is freely available for redistribution 